\title{
B-28 スキーターンにおけるたわみと圧カに関する測定と考察
}

\author{
Measurement and Investigation on the Ski Deflection and Ski-Snow \\ Contacting Pressure During the Turn on the Snow
}

\author{
○北出＼cjkstart基紀（金沢大院），米山＼cjkstart猛（金沢大），長田和隆（小賀坂スキー製作所）
}

Motoki KITADE(Kanazawa University), Takeshi YONEYAMA(Kanazawa University), Kazutaka OSADA (Ogasaka ski company)

Deflection of the ski, ski-snow contacting pressure, boot-ski loads have been measured during the turn on the snow slope on the two skis of different bending stiffness distribution. The result shows that the ski-snow contacting pressure distribution is different in spite of that boot-ski loads and ski deflections are similar in the same carving turn remaining the same snow groove. From the deflection data, snow groove dimensions and measured pressure distribution, ski-snow contacting situation have been estimated by the correspondence between the deflected edge line with edged ski sliding surface and the snow groove surface. The idea that the front part of the ski bends to compress the snow surface and rear part of the ski rides on the formed snow groove surface is validated from the investigation. The difference of the ski-snow contacting pressure distribution attributes to the difference in the bending stiffness distribution of the ski.

Key Words: Sports engineering, ski, turn, measurement, deflection, pressure

\section{1. 緒 言}

ターン中のスキーのたわみと雪面との接触圧力を知るこ とは,ターンメカニズムの解明のためにも，スキーの設計の ためにも必要なことである。筆者らは,これまで,ターン中 のスキーのたわみを検出するたわみセンサビームを開発す るとともに, スキーと雪面との接触面における圧力を測定す る方法を開発し，カービングターン中の実働のたわみと接触 圧力分布の測定を行った. その結果ロングターンにおいて, スキーのたわみにはゆれがともないながらも舵取り期にお いて，ほぼ一定のたわみを維持し，そのたわみ形状は 3 点曲 げのたわみ形状とは異なること, 個々の箅所の圧力は激しく 変動するものの, 平均処理すれば, 一様な圧力分布を呈する ことなどがわかった．またスキー前部において，圧力の増減 とたわみの増减が連動し，たわみが大きいときに雪面からの 圧力も大きくなることも示した.

雪面溝とスキーとの接触状態についても推定したが，その 推定方法を明確にし，スキーと雪面との接触状態とターンメ カニズムを考察するための基礎を明らかにする必要がある.
一方, スキーの設計において, スキーの曲げ岡性分布をど う与えるかが重要な課題である. スキーの曲げ剛性の違いに よって, たわみや雪面圧力はどう異なるのかを調べ, 剛性分 布の与え方についての設計指針を得たい。

そこで, 本研究では, たわみ, 圧力と雪面溝との関係から, スキーと雪面との接触状態を推定する方法を詳しく検討す る. 曲げ剛性分布の異なるスキーを用いて, たわみ, 圧力, 荷重, 雪面溝の測定を行い, スキーの剛性による違いについ て調べる.

\section{2. 測 定 装}

\section{1 たわみセンサ}

たわみセンサビームの概略を図 1 に，実際にセンサビーム と圧力センサを取り付けたスキー板を図 2 に示す. ターン 中のスキー板のたわみを計測するためのセンサは, 曲げ角度 を検出するセンサ（曲げセンサと呼ぶ）を $6 \mathrm{~mm}$ 角のアルミ ニウムビームを介して接続し, スキー板の上面にとりつけた ものである.曲げセンサを,ブーツセンターより前側に5個，

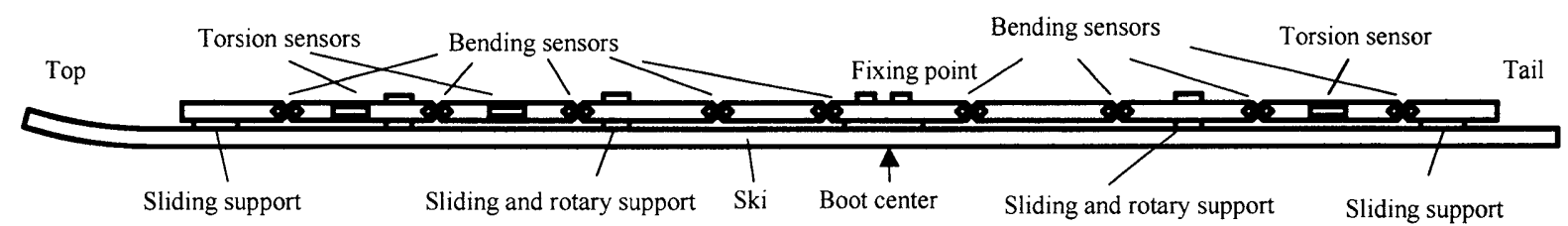

Fig.1 Structure of the deflection sensor beam

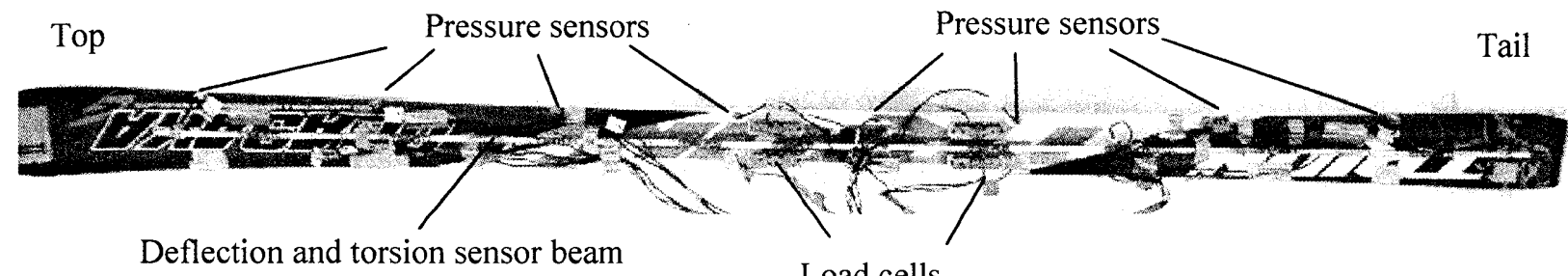

Load cells

Fig.2 Ski with a deflection sensor beam and pressure sensors 
後乃側に 4 個を配置した. 曲げセンサの構造は図 3 のように 十字ばねの薄板にひずみグージを貼り付けたものである.

本研究で使用したスキー板の全長は $1750 \mathrm{~mm}$ で, たわみセ ンサビームの長さはブーツセンターより前方に $800 \mathrm{~mm}$, 後 方に $700 \mathrm{~mm}$ とした，センサビーム全体の質量は約 $0.2 \mathrm{~kg}$ で ある.スキー板の滑走面を平らにした状態をゼ口点としてた わみゼロとし, 各曲げセンサで検出した角度とそれらをつな ぐビ一ムの長さから各センサ点の位置を求め, それらをつな いでたわみ曲線を求める。

なお，以後の測定結果でねじりについては記述しないが， たわみセンサビームにはねじりを検出するためのねじりセ ンサも有している.

\section{2 圧カセンサ}

雪面での滑走中の圧力を実測する方法として，市販の直径 $6 \mathrm{~mm}$ の圧力センサをスキー板滑走面に装着して測定した。

使用した圧力センサは共和電業製小型圧力センサ PS $10 \mathrm{~KB}$ (定格圧力 $1 \mathrm{MPa}$ ) である. センサの感受部分はダイヤ フラム構造で, 受圧面が圧力を受けて生ずるたわみによって 生じるひずみをひずみゲージで検出するものである.図 40 ように，压力センサの受圧面が滑走面と同一になるようにセ ンサの高さを合わせて固定した．压力センサはスキー板の右 エッジ側に 8 箇所取り付けたので, 左足に履いたときに右夕 ーン外足のエッジ側圧力が測定される.

\section{3 荷重センサ}

スキーヤーからスキーへ作用する荷重を検出するセンサ を図 5 に示す.ビンディングプレートとスキーとの間に設置 するもので, ビンディングプレートから受ける荷重を中央の ピンジョイント部で受け，前後で支えているビームの側面に 45 度方向にひずみゲージを貼り付けて検出する.せん断力を 検出する構造としたので, 高さの低いコンパクトな構造とな った。この荷重センサを図 6 のように，ブーツセンターから 前後 $110 \mathrm{~mm}$ の位置に, 前 2 個, 後乃 2 個の、計 4 個を装着 した.ブーツセンター前左側のロードセルを FL、前右側を FR、同様にブーツセンター後方の左側を RL、後右側を RR と名付ける。

\section{3. 測 定}

\section{1 スキー}

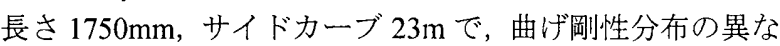
る 2 種類の GS 競技用スキーを用いて測定した。 2 種類の板 の剛性分布を図 7 に示す. 板 $\mathrm{A}$ は、ブーツセンター付近の剛 性が、板 B と比較して低く, 板 B は, ブーツセンターより 後方で最も曲げ剛性が高くなっている。

\section{2 データ収集}

測定システムを装着した被験者を図 8 に示す，センサを取 り付けたスキーを左足に履き，滑走中のそれぞれのデータを， 肩掛忛リック内にある，市販データロガー（キーエンス NR-ST04 および NR600）で記録した. データサンプリング 周期は $2 \mathrm{~ms}$ とした。

\section{3 測定}

測定は、2009 年 3 月 18 日、志賀高原高天原スキー場にて 行った，気温は 5 度，新雪の圧雪状態であった。被験者は、 身長 $185 \mathrm{~cm}$ 、体重 $90 \mathrm{~kg}$ の上級スキーヤーである. 滑走場所の 斜度はおよそ 20 度で, 長さ $300 \mathrm{~m}$ の滑走雪面において 4 周期 程度のロングターンを行った. 滑走後, 雪面に残ったターン の軌跡を測定した。スキーA とスキーB の左スキーにそれぞ れたわみセンサビ一ム, 圧力センサ, 荷重計を取り付け, ス キーA でターンした後，スキーB に履き替えた後，スキーB で同様の滑走をおこなった。それぞれの時刻で気温に差が

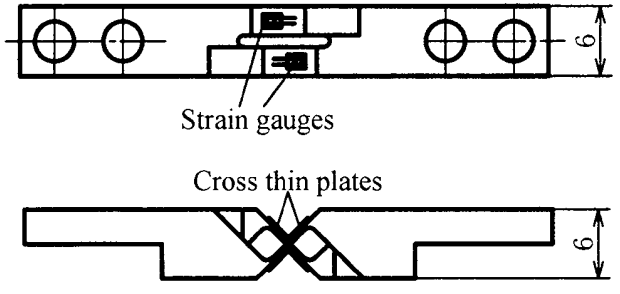

Fig.3 Structure of the bending sensor in the deflection sensor beam
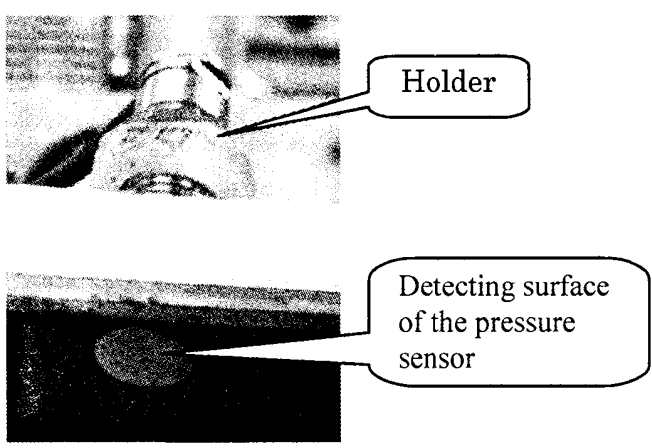

Fig 4 Pressure sensor equipped near the ski edge

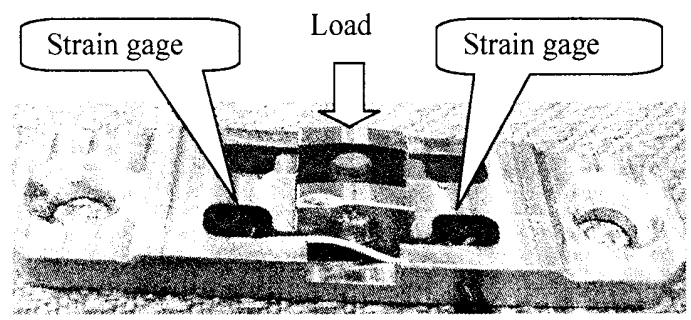

Fig.5 Load cell for binding-ski load

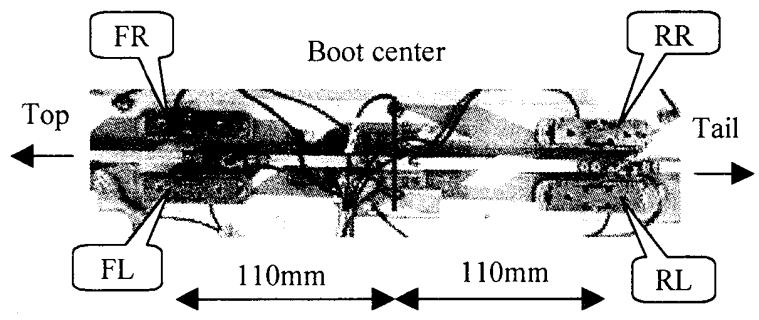

Fig.6 Location of the 4 load cells

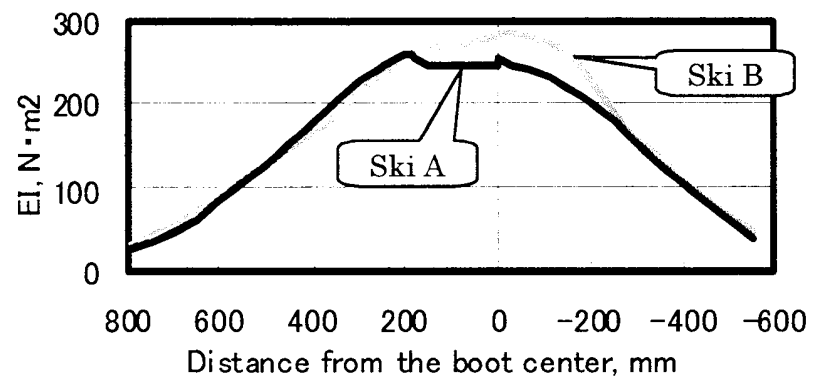

Fig.7 Bending stiffness distributions of the two skis 


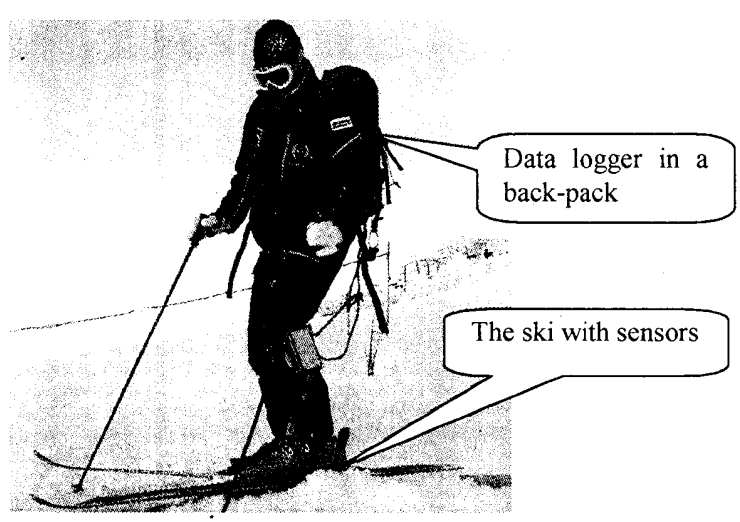

Fig.8 A skier with measuring system

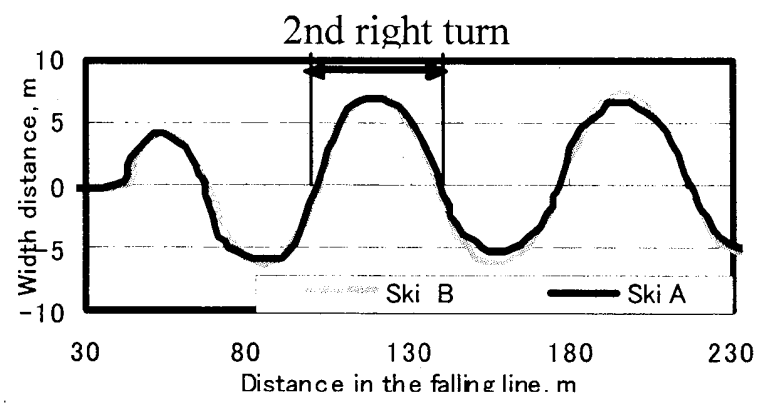

Fig.9 Turn trajectory

なく, ターンを行った雪面状態は同様であった.

\section{1 滑走軌跡}

\section{4. 測 定 結 果}

滑走後の滑走軌跡を図 9 に示す. 左から右へ斜面を下る方 向である，板の特性による違いを得るために，スキーヤーは それぞれの滑走で，ほぼ同じ軌道を滑っている，第 2 右ター ン中盤におけるターン半径は約 $30 \mathrm{~m}$ で、通過時間から求めた ターン中の平均速度は $19 \mathrm{~m} / \mathrm{s}(67 \mathrm{~km} / \mathrm{h})$ であった。

\section{2 荷重}

第 2 ターンにおける外足（左足）スキーにかかる荷重の変 化を図 10 に示す。 スキーA における荷重が図 10(a), スキー B における荷重が図 10(b)である.ターンの中盤以降におい ては，かかと内側にかかる荷重 RRがつま先内側にかかる荷 重 FR よりも大きい。外エッジ側にはほとんど荷重が作用し ていない.ターン中盤における 4 点の荷重を比較したものを 図 11 に示す.どちらのスキーを用いても 4 点の荷重のかけ 方には大きな違いがないことがわかる。

\section{3 たわみ}

第 2 ターン中盤における左足（外足）スキーのたわみを図 12 に示す. 0.2 秒間（100 点）の平均值を示す.ブーツセンター より前部のたわみはスキーBの方がスキーAよりも少し大き い.ブーツセンターより後部のたわみは，スキーA とスキー B でほぼ同様である。

\section{4 雪面㴖}

滑走後に雪面に残った溝の様子と断面寸法を図 13 に示す. スキーAのターンにおいてもスキーB のターンにおいても 溝深さはほぼ同様で, 溝の外側（スキーの滑走面と当たる面 の幅は 40～50mm 程度で，この面注滑走前の雪面よりも硬く
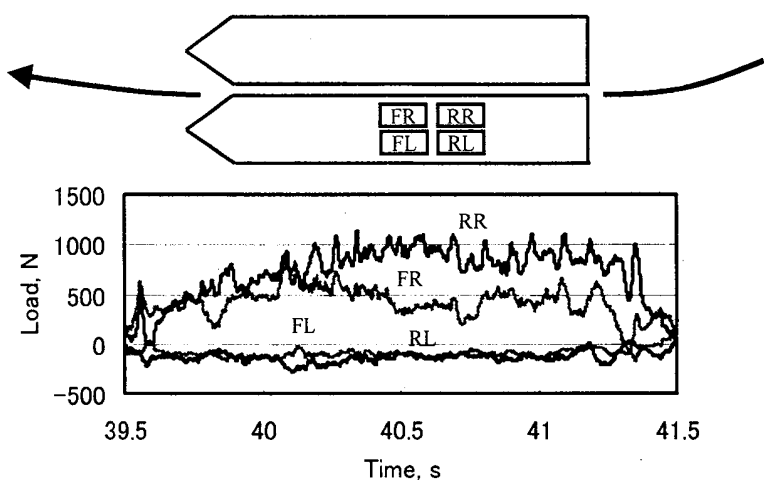

(a) Eoads on ski A

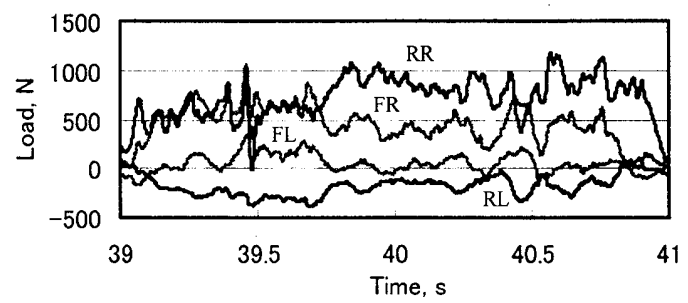

(b) Loads on ski B

Fig.10 Comparison on the loads on the left ski during the right turn

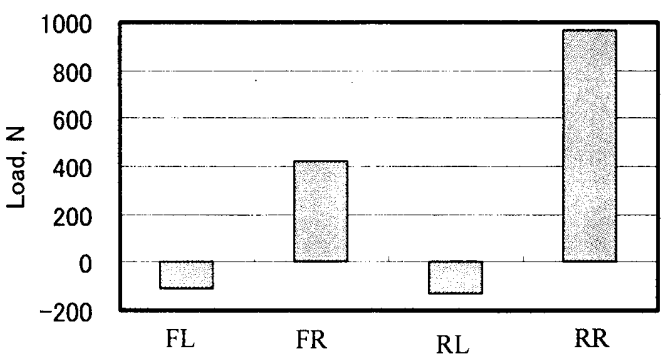

(a) Loads in ski A

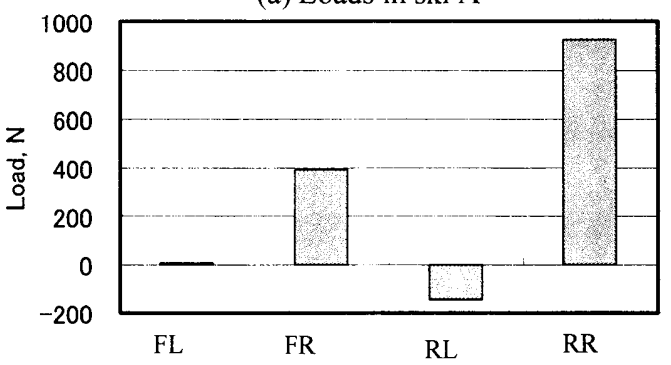

(b) Loads in ski B

Fig.11 Comparison of the loads on the four points at the middle of the turn arc

締まった表面となっている。この面が雪面となす角度は約 $55^{\circ}$ で，スキーのエッジ角度がこの值であったと考えられる。 一方溝の内側の面はターンの半径方向に少しカーブした曲 面となっており, 雪面を切り取った断面となっていて, 締め 固まった面ではない. また溝の外側面と内側面とのなす角度 は約 $110^{\circ}$ 程度あり，90よりも大きい。 


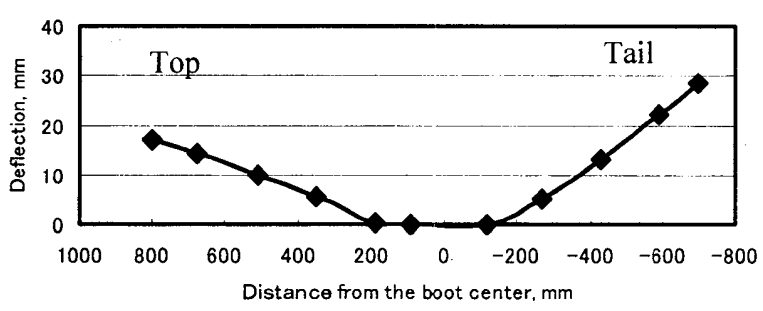

(a) Deflection of ski A

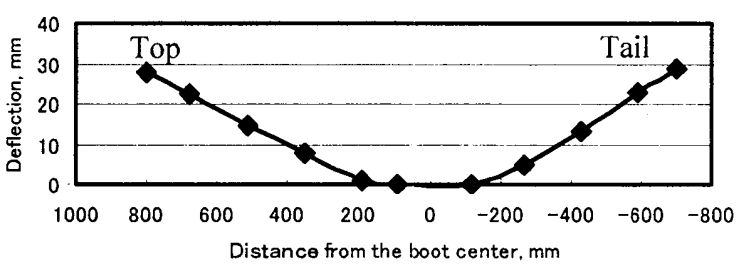

(b) Deflection of ski B

Fig.12 Comparison of the ski deflection in the middle of the turn arc

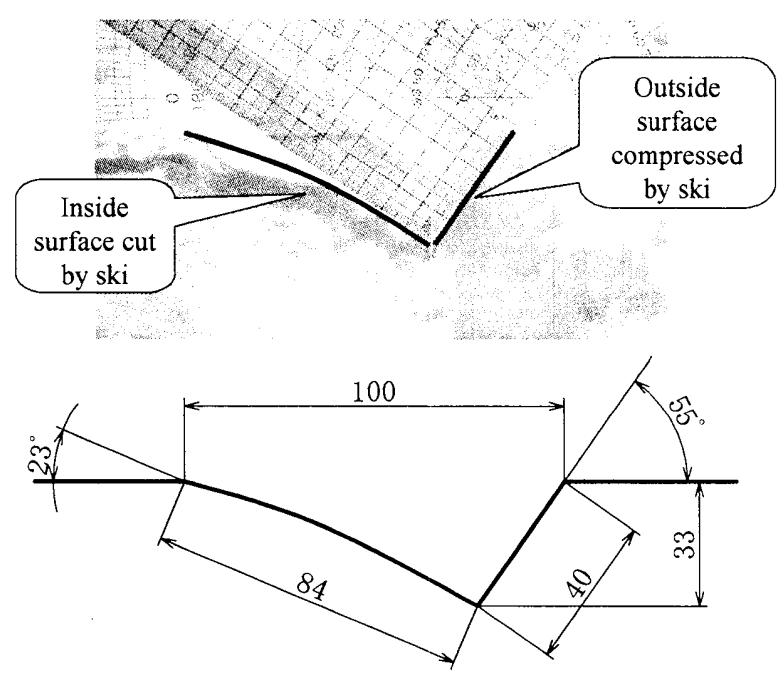

Fig.13 Dimensions of the cross section of the snow groove

\section{5 雪面圧力分布}

第 2 ターン中盤における圧力分布の比較を図 14 に示す. スキーA においては，ブーツセンター前方 $200 \mathrm{~mm}$ から後方 $400 \mathrm{~mm}$ 程度の領域において，圧力がほぼ平坦である。スキ 一の前方 800〜 600 mm における圧力は低い. スキー後部（一 $600 \mathrm{~mm}$ ）における圧力も比較的高い。 それに対し，スキーB では，ブーツセンター部において一旦圧力が低下し，ブーツ センターの後方 $350 \mathrm{~mm}$ 付近で最大となっている。 つまりブ 一ツセンターの前後に圧力のピークがある. その值はスキー Aよりも低い.一方スキ一前方 800〜 400 $\mathrm{mm}$ における圧力は スキーAよりも高くなっている. 逆にスキー後部 $(-600 \mathrm{~mm})$ における圧力は低い.

このように，スキーAにおいては，ブーツセンター前後の 圧力が平坦であるものの，比較的後方の圧力が高く，スキ一 B では，ブーツセンタ一前後に圧力のピークがあり，比較的 スキー前方の圧力が高くなっている.

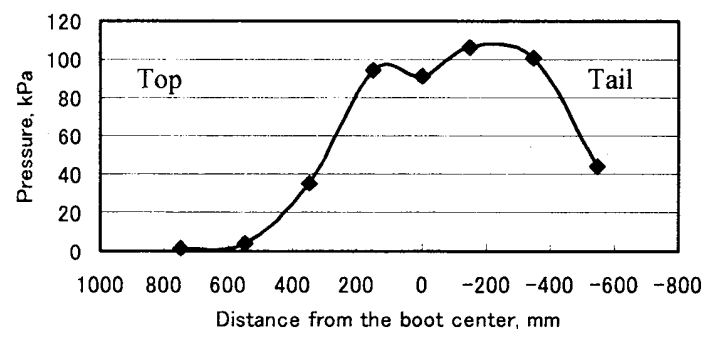

(a) Pressure distribution on ski A

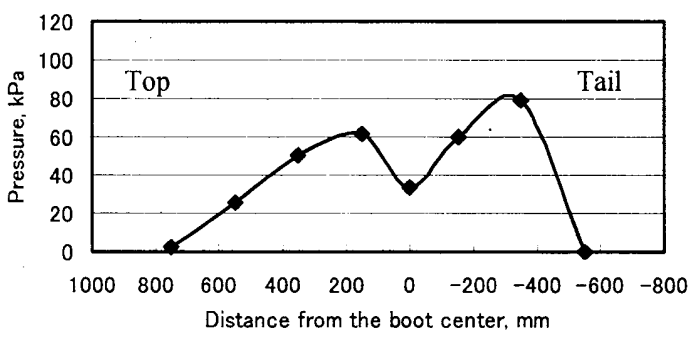

(b) Pressure distribution on ski B

Fig. 14 Comparison on the ski-snow contacting pressure distribution in the middle of the turn arc

\section{5. 考察}

\section{1 圧カと雪面濩との関係}

スキーの剛性分布の違いによる荷重やたわみ, 圧力の違い を測定したが，これらの相互関係を分析する上で，基礎とな るスキーと雪面の接触状態についてまず考察する.

図 13 のように雪面溝の外側面が雪面と $55^{\circ}$ の角度をなし ていることから，スキーはおよそ $55^{\circ}$ のエッジ角（角付け） を持つと考えられる. この角度は, ターン半径とターン速度 から求められる遠心力と重力とからスキーヤーに作用する 力の方向と照らし合わせても妥当な值である.

ターンの間, 雪面に対してスキーはこのエッジ角を持って 押し付けられ，雪面が圧縮される. 雪面溝における外側面 (ス キ一滑走面との接触面）が硬く締まっていることから，この 面がスキーによる圧縮によって締め固まったと考えられる. つまりスキーを雪面に押し込んでその力を支えられるほど 雪面との接触面が固くなったところまで溝深さが形成され ると考えられる。したがって雪面が硬いほど溝は浅く, 雪面 が柔らかいほど, 圧縮されて硬くなるまでの変位を必要とす るので, 溝が深くなると考えられる. 図 14 のように, 雪面 からスキーに作用する圧力はスキー前部から後方に向かっ て高くなり, ブーツセンター付近で最大となった後, 後方で また減少している. 圧縮された溝の深さはその梁さまで圧縮 された圧力よりも高い圧力が作用しないとさらに染くはな らないと考えられるので, 最大圧力よりも低いスキー後部で は, 雪面の溝の深さは変わらないと考えられる.したがって, スキーにおいて, 圧力ピークよりも低い後部は掘りこまれた 雪面溝の面の上に載っている状態にあると考えられる. また 逆にスキー後部で圧力が検出されていることから, スキー後 部が雪面よりも上空に持ち上がっているのではなく, 雪面と 接触していることが裹付けられる。

一方スキー先頭部から最大圧力点までは徐々に雪面を押 し込んでいる過程であると考えられる.ターン軌道上を進行 することで溝が形成されるので, スキ一の先端部から雪面の 押し込みが始まり,ブーツセンター付近の最大圧のところま で溝の圧縮が進行する。この過程における圧力には，雪面を 
圧縮する圧力以外に進行方向逆向きに雪がスキーにぶつか ってターン円弧より外側に吹き飛ばされる抵抗も含まれる と考えられる。

\section{2 スキーのエッジラインと雪面满との関係}

前節の圧力と雪面溝との関係についての考えをもとに, た わんだスキーが雪面溝と接触している状態を推定する. スキ 一のエッジラインが雪面に対してどのような関係になって いるかを求めるため, 図 15 のように，スキーのたわみから エッジラインを求める。まず計測されたスキーのたわみは, スキー中央線に平行なたわみ曲線であると考えられるため， 図 15(a)に示すようにサイドカーブの曲線に沿って幅方向の 変位を与え, エッジラインのたわみ曲線を求める. 次にスキ 一をエッジ角分だけ進行方向を軸に回転させれば雪面に対 するエッジラインが求まることになるが， 5.1 で述べたよう にスキー後部は雪面溝の上に載っていると考えられること から，スキー後部のエッジラインと雪面との距離はブーツセ ンター付近における距離とほぼ同一であると考えられる。 そ こで, エッジ角だけ回転させた後のスキ一後部のエッジライ ンが雪面とほぼ平行になるように図 15(b)のようにスキーの 前方を少し持ち上げた上で図 15(c)のように，進行軸周りに エッジ角だけ回転させる.

スキーA のたわみについて，ブーツセンター後方 $120 \mathrm{~mm}$ の位置を中心に $2^{\circ}$ だけ前方を持ちあげ，エッジ角度 $55^{\circ}$ だ け回転させたエッジラインを雪面に垂直な上方向から見た ラインを図 16(a)に示す. 合わせて半径 $30 \mathrm{~m}$ の円弧を示す. この図からスキー後部が半径 $30 \mathrm{~m}$ の円弧とほぼ一致してお り，ターン溝と一致する. スキー先頭のエッジは雪面まで持 ちあがっている部分であり, 雪面溝の内側面の縁を形成する 部分であると考えられる. 一方このエッジラインを雪面に平 行な方向から見たのが図 16(b)である.ブーツセンターより 後方はほぼ水平で, スキー先頭部の高さは雪面溝の底から雪 面までの距離に相当する.

\subsection{3 次元モデルによる接触状態の検証}

たわんだスキーと計測された雪面溝の3次元モデルを作り， スキーと雪面との接触状態について検証する.

雪面溝モデル上にたわんだスキー板を合わせた状態を雪 面に垂直な上方から見たのが図 17(a)である，スキーのブー ツセンターより後部を雪面溝上に載るように置いたもので ある. ブーツセンターより前方のエッジラインが雪面溝の内 側面の縁に向かっており, 図 16(a) と対応している。 また雪 面に平行な方向から見たのが図 17(b)である。ブーツセンタ 一より後部が雪面と平行で, ブーツセンターより前部が上方 にむかっており, 図 16(b)に対応したエッジラインとなって いる.

さらに，スキ一前方を，溝が形成される前の雪面として， スキーの滑走面と雪面との接触領域を示したのが図 17(c)

である.雪面と接触する幅はスキー先端部からブーツセンタ 一部へかけて徐々に幅が広くなり，ブーツセンター部以降は ほぼ一定になっている.

この 3 次元の接触状態の図を斜め方向から見た図を図 18 に示す.ブーツセンター部での横断面を見ると, 雪面溝の外 側の面上にスキー板が載っていることを確認できる.

\section{4 スキーの㽤性とたわみ・圧カとの関係}

スキーの特性として曲げ剛性分布が与えられ，一定の斜度 の雪面上において所定のターン軌道を所定の速度で滑走す ることを条件とすると, 遠心力と重力から, ブーツを通して スキーに作用する力の総力がほぼ決まる.ブーツからスキー へ力が作用するときに, 通常は前後のビンディングを通るた め, スキーへの力は前部のビンディングと後部のビンディン

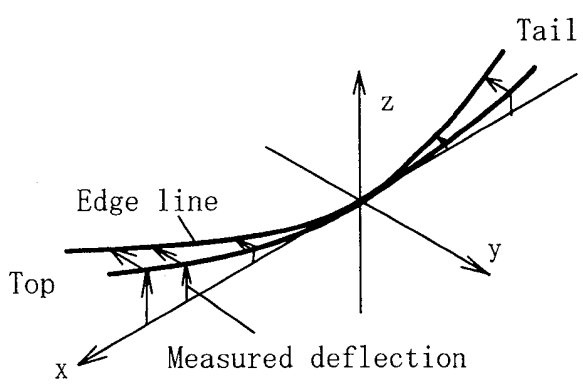

(a) Calculation of edge line from the deflection data

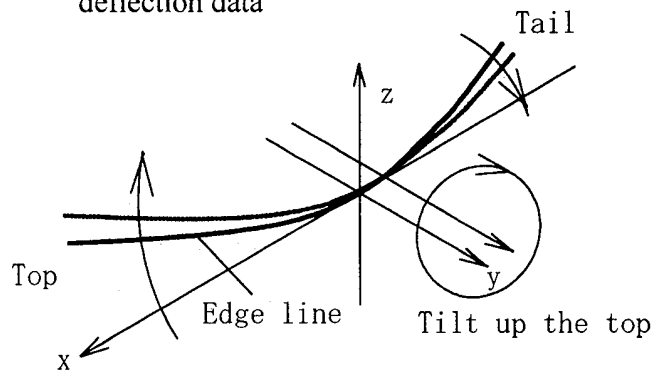

(b) Tilting of the top

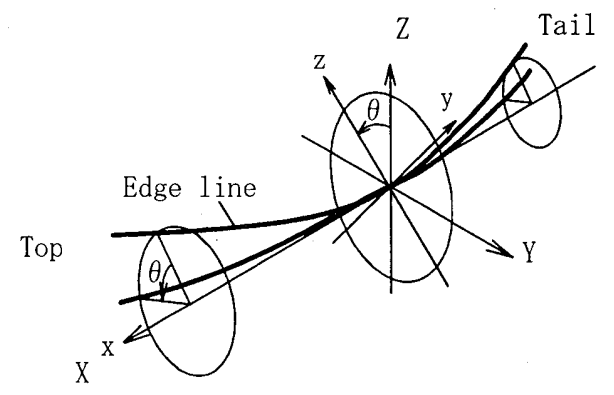

(c) Rotation by edging angle with the skiing direction

Fig.15 Investigation of the edge line of the ski on the snow surface

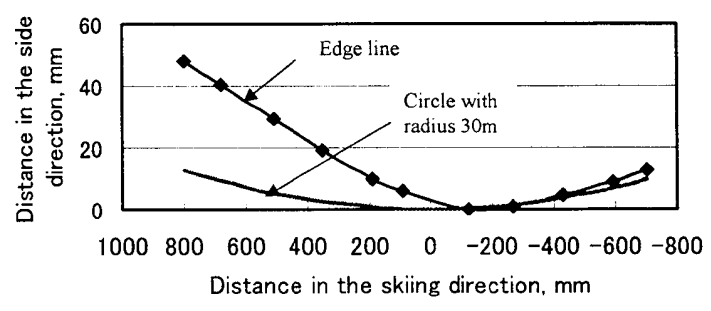

(a) Edge line from the view of vertical direction to the snow surface

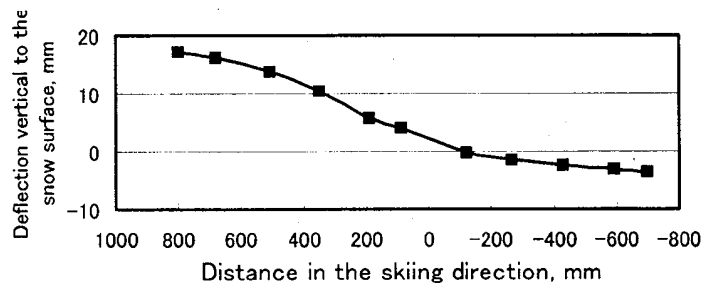

(b) Edge line from the view of parallel direction to the snow surface

Fig.16 Estimated edge line of the ski 
(a) Edge line from the view of vertical direction to the snow surface

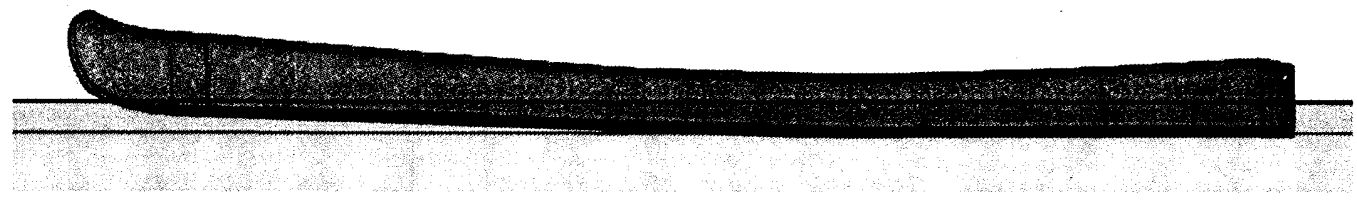

(b) Edge line from the view of parallel direction to the snow surface

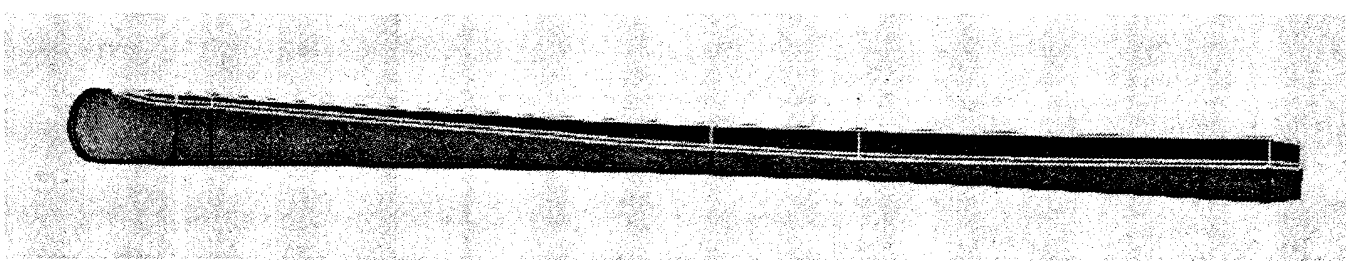

(c) Contacting area between ski and snow

Fig.17 Investigation of the edge line of the ski and contacting surface between ski and snow by 3D model

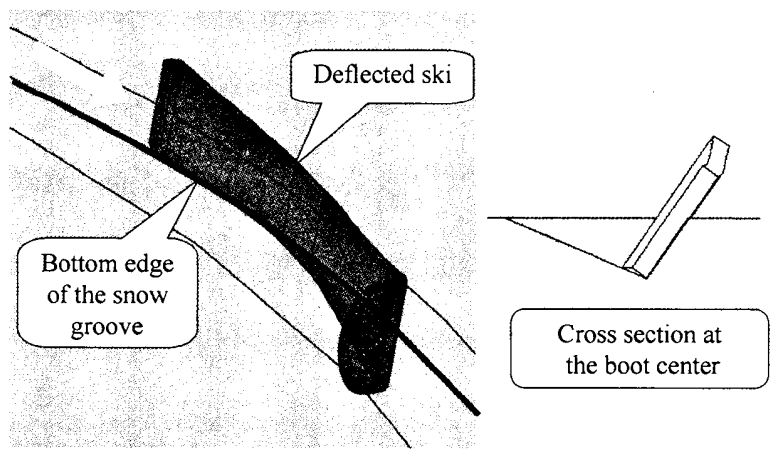

Fig.18 Fitting of the deflected ski on the groove

グを通して与えられ，本測定で示した 4 点荷重のような状態 でスキーに作用すると考えられる. 前後の荷重の配分は本測 定で検出されたものが一例となる。このような荷重によって, 角付けされたスキーが雪面に押し込まれ，雪面との接触面が 荷重を支える硬さまで掘りこまれた状態まで雪面溝が形成 される。このとき，スキ一のたわみは，スキー後部が雪面溝 の上にのり, 先頭部は雪面溝の内側面の縁にあるように形成 される.スキーのたわみは, ブーツからの荷重と雪面からの 圧力分布に対して, スキーの曲げ用性分布に対応して形成さ れると考えられる。本測定では，ブーツからスキーへの作用 荷重がほぼ同一で，たわみや雪面溝もほぼ同様であった。紙 面の都合で詳細は省略するが，雪面の圧力分布と接触幅から， 雪面からスキーに作用する荷重分布を推定し，モーメント分 布を求めてスキーの剛性分布から曲率を求めてたわみを算 出すると，たわみと圧力分布との関係が測定結果とほぼ同様
になった。したがって雪面圧力分布の違いは，スキ一の剛性 分布の違いに起因するものと考えられる.

雪面溝の形成においては，スキー板の押し込み圧力と雪面 溝の深さとの関係など雪面の圧縮特性がからんでおり, また たわみによって形成される迎え角による抵抗の大きさも関 係する。このような雪面特性を考慮してたわみと発生する圧 力分布の予測ができれば，スキーの曲げ剛性設計に役立つと 期待される。

\section{6. 結苇}

ターン中のスキーのたわみ，圧力，荷重を計測するシステ ムを用いて, 曲げ岡性分布の異なるスキーを用いてターンを 行い, 比較を行った. その結果, たわみや荷重にはあまり違 いがないものの, 雪面圧力分布に違いが見られた。計測され たスキーのたわみと圧力分布, 雪面溝のデータから, スキー と雪面溝との接触状態を推定し, ブーツセンターより前方で 雪面が押し込まれ，ブーツセンター後方では形成された溝の 上にスキ一板が載るモデルの妥当性を検証した。 これらの接 触条件をもとに, 雪面圧力分布の違いがスキーの曲げ剛性分 布の違いに起因することを検討した。

\section{文献}

(1) Yoneyama, T., Scott, N., Sports Engineering, Vol.11,No.1(2008), pp.3-13.

(2) Scott, N., Yoneyama, T., Sports Engineering, Vol.10, No.3(2007), pp.145-156.

(3) Yoneyama, T., Kagawa, H. \& Scott, N., Proc. 6th International Engineering of Sport (2006), pp 293-298.

(4) Yoneyama, T.,Kagawa,H., Tatsuno D., Scott, N. and Osada K.,Transactions of the Japanese Society of Mechanical Engineers, Series C, Vol.75, No.752 (2009), pp.336-343. 